\title{
Prevalence and Antibiotic Resistance Pattern among the Mastitis Causing Microorganisms
}

\author{
Karanvir Singh1, Mudit Chandra ${ }^{1 *}$, Gurpreet Kaur ${ }^{1}$, Deepti Narang1, Dhiraj Kumar Gupta ${ }^{2}$ \\ ${ }^{1}$ Department of Veterinary Microbiology, College of Veterinary Science, Guru Angad Dev Veterinary and Animal Sciences \\ University, Ludhiana, India \\ ${ }^{2}$ Department of Veterinary Clinical Medicine, College of Veterinary Science, Guru Angad Dev Veterinary and Animal Sciences \\ University, Ludhiana Punjab, India \\ Email: *drmuditchandra@rediffmail.com
}

How to cite this paper: Singh, K., Chandra, M., Kaur, G., Narang, D. and Gupta, D.K. (2018) Prevalence and Antibiotic Resistance Pattern among the Mastitis Causing Microorganisms. Open Journal of Veterinary Medicine, 8, 54-64.

https://doi.org/10.4236/ojvm.2018.84007

Received: February 22, 2018

Accepted: April 27, 2018

Published: April 30, 2018

Copyright $\odot 2018$ by authors and Scientific Research Publishing Inc. This work is licensed under the Creative Commons Attribution International License (CC BY 4.0).

http://creativecommons.org/licenses/by/4.0/

Open Access

\begin{abstract}
Mastitis is one of the most commonly occurring diseases of dairy animals. It is the most important cause of economic losses to the dairy industry in India and throughout the world. In the present study prevalence of microorganisms isolated from mastitic milk and their antibiotic resistance was studied. A total of sixty nine milk samples from mastitic animals (clinical and subclinical) were tested using sodium lauryl sulphate test and those positive were selected and transported to the laboratory for isolation and identification of the causative agent. Out of these samples fifty samples yielded bacterial growth when tested on selective/non selective medium. Of these fifty samples, seven samples had single bacterial growth whereas rest of the 43 samples had mixed growth. Among the bacterial isolates it was found that the highest prevalence was of Streptococcus agalactiae and Staphylococcus aureus followed by E. coli and Klebsiella pneumoniae. Antibiotic sensitivity test revealed that Streptococcus agalactiae revealed the highest sensitivity to ofloxacin, ciprofloxacin, gentamicin and resistance to amoxicillin and doxycycline; Staphylococcus aureus revealed the highest sensitivity to ciprofloxacin, doxycycline, azithromycin and sparfloxacin and resistance to amoxycillin and gentamicin. Similarly, E. coli revealed the highest sensitivity to azithromycin and chloramphenicol and resistance to amoxicillin and teicoplanin, and Klebsiella pneumoniae revealed highest sensitivity to azithromycin, gentamicin and resistance to amoxicillin, teicoplanin and erythromycin. Thus, from the present study it could be concluded that Streptococcus agalactiae, Staphylococcus aureus, E. coli and Klebsiella pneumoniae were the most frequently isolated organisms from mastitic animals and azithromycin and the third generation fluoroquinolones (ciprofloxacin, sparfloxacin and ofloxacin) were the most sensitive drugs.
\end{abstract}




\section{Keywords}

Mastitis, Milk, Antibiotic, Bacteria, Resistance

\section{Introduction}

India ranks number one in the world in terms of total milk production with 146.3 million tones of milk produced annually [1]. Mastitis is one of the most commonly occurring diseases of dairy animals causing huge economic losses to the dairy industry in India and throughout the world [2]. Mastitis is the inflammation of the udder tissue parenchyma characterized by pathological changes in the mammary gland tissues such as edema, redness, and increase in the gland temperature as well as several changes in the physical and chemical properties of the milk [3].

The consequence of mastitis is restricted not only to the dairy farmers but is also a concern to the consumers because of increasing antimicrobial resistance due to the extensive and indiscriminate use of antimicrobials for the management of mastitis [4]. It has been reported that more than 150 bacterial species implicated with the mastitis and they have been categorized into three main categories viz., environmental, contagious and opportunistic [5].

Primarily diagnosis for mastitis is based on the physiological symptoms, such as swelling and inflammation of the mammary gland or apparent changes in the milk. Because, such symptoms appear only at the chronic or clinical state of mastitis, its earlier diagnosis relies on multitude of simple diagnostic methods. Among these the most commonly employed methods are the measurement of somatic cell count and enzymatic analysis, but, these simple methods hold many discrepancies which could increase the likelihood for false positive or false negative results.

Isolation of bacteria from the aseptically collected milk sample is considered as gold standard. These isolated bacteria could be subjected to antibiotic sensitivity test to know the sensitivity pattern prevailing. Keeping in view the above facts the present study was designed with an objective to isolate and identify bacteria from the mastitic milk and to study their antibiotic sensitivity and resistance pattern.

\section{Materials and Methods}

\subsection{Sampling}

Milk samples (15 - $20 \mathrm{ml}$ ) from mastitic (subclinical and clinical) were collected aseptically after discarding first few streaks of milk from the Teaching Veterinary Clinical Complex, GADVASU, Ludhiana and also from the nearby dairy farms in and around Ludhiana. These samples were collected from January, 2017 till June, 2017. These milk samples were tested with the SLS test by adding three $\mathrm{ml}$ of milk and $3 \%$ sodium lauryl sulphate test reagent (SLS). The mixture was 
rocked in the horizontal plane to record the positive reaction as indicated by a gelatinous mass collected near the center of the well. Samples positive via SLS tests were kept on ice and transferred immediately to the laboratory and were subjected for isolation of bacteria.

\subsection{Isolation of Bacteria}

Milk samples brought to the laboratory were mixed thoroughly and one loop full of the milk sample was inoculated on Brain Heart Infusion (BHI) Agar, Eosin Methylene Blue (EMB) Agar, MacConkey's Lactose Agar (MLA), Baird Parker Agar (BPA) supplemented with egg-yolk tellurite emulsion, Edward's medium and Blood Agar (BA) (Hi Media, Mumbai). Later, these inoculated plates were incubated at $37^{\circ} \mathrm{C}$ for $16-24$ hours. The isolated bacterial colonies were subjected to Gram's staining for the identification of gram positive and negative and were subjected to various biochemical tests (catalase, oxidase, indole, methyl red, voges proskauer's, citrate, triple sugar iron etc) for confirmation.

\subsection{Antibiotic Sensitivity Testing}

All the isolates were tested to fifteen antibiotics which were divided into groups consisting of Quinolones [ciprofloxacin ( $5 \mathrm{mcg}$ ), gatifloxacin $(5 \mathrm{mcg}$ ), ofloxacin (5 mcg), sparfloxacin (5 mcg)], Penicillin and cephalosporins group [amoxicillin (10 mcg), cephalexin (30 mcg)], Macrolides [azithromycin (15 mcg), erythromycin $(15 \mathrm{mcg})$ ], Aminoglycosides [gentamicin $(10 \mathrm{mcg})$ ], Tetracyclines (tetracycline $(30 \mathrm{mcg})$, doxycycline $(30 \mathrm{mcg})$ ), Glycopeptides [vancomycin $(30 \mathrm{mcg})$, teicoplanin $(30 \mathrm{mcg})$ ], chloramphenicol $(30 \mathrm{mcg})$ and co-trimoxazole $(25 \mathrm{mcg})$ on Muller Hinton Agar (MHA). In brief, overnight grown culture of individual bacteria in Luria Bertani (LB) broth was uniformly spread onto a Muller Hinton Agar plate with the help of a sterilized cotton swab and antibiotic discs were placed on it and these plates were incubated for $16-24 \mathrm{~h}$. Next day, the zone of sensitivity was measured using a ruler and the diameter of the zone was recorded in millimeters $(\mathrm{mm})$. All the isolates were classified as sensitive, intermediate and resistant on the basis of zone of inhibition as per the standard guidelines of CLSI [6].

\subsection{Extraction of DNA from the Bacterium}

The extraction of genomic bacterial DNA was done using Phenol: Chloroform: Isoamyl alcohol (25:24:1) (PCI) as per the method of Sambrook and Russell [7]. In brief, $1.8 \mathrm{ml}$ of overnight grown bacterium in LB broth was centrifuged and to the pellet, $50 \mu \mathrm{l}$ each of $10 \%$ SDS (Sodium Dodecyl Sulphate) and Proteinase K $(200 \mu \mathrm{g} / \mathrm{ml})$ were added and incubated at $60^{\circ} \mathrm{C}$ for $1 \mathrm{~h}$. Next, $500 \mu \mathrm{l}$ of PCI (25:24:1) was added to it mixed gently and centrifuged (10,000 g) for 10 minutes to collect the supernatant. The PCI step was repeated and the supernatant was collected. To the supernatant equal volume of isopropanol and $1 / 10^{\text {th }}$ volume of the supernatant $3 \mathrm{M}$ Sodium acetate $(\mathrm{pH}-5.2)$ was added and kept at $-20^{\circ} \mathrm{C}$ for 
overnight. Next morning, the tube was centrifuged (10,000 g) for 20 minutes to collect the pellet. The pellet was washed twice with $500 \mu \mathrm{l}$ of $70 \%$ ethanol and after removal of the residual ethanol; the pellet was reconstituted in $50 \mu \mathrm{l}$ of nuclease free water (NFW) and stored at $-20^{\circ} \mathrm{C}$ for further use.

\subsection{PCR for the Identification of Bacterium}

PCR was carried out using genus specific primers for E. coli, Klebsiella pneumoniae, Staphylococcus aureus and Streptococcus agalactiae individually (Table 1) designed using Primer 3 Software [8] and tested in silico. A reaction mixture consisting of $2.5 \mu \mathrm{l}$ of 10X PCR buffer (New England Biolabs Inc., USA), $1 \mu \mathrm{l}$ of $20 \mathrm{pmol} / \mathrm{ul}$ of each forward and reverse primers (Flarebio Biotech Inc., China), $0.6 \mu \mathrm{l}$ of $50 \mathrm{mM} \mathrm{MgCl}_{2}$ (New England Biolabs Inc., USA), $1 \mu \mathrm{l}$ of $10 \mathrm{mM}$ dNTPs mix (New England Biolabs Inc., USA), $0.2 \mu \mathrm{l}$ of $5 \mathrm{U} / \mu \mathrm{l}$ of Taq DNA polymerase (Genxbio Health Sciences Pvt. Ltd., India), $2 \mu \mathrm{l}$ of individual template DNA containing approximately $100 \mathrm{ng}$ of DNA and the reaction volume was made to $25 \mu \mathrm{l}$ by adding nuclease free water. PCR was performed on a thermocycler (Veriti, Applied Biosystems, USA) with the following conditions; an initial denaturation at $94^{\circ} \mathrm{C}$ for 5 minutes and 35 cycles each of $94^{\circ} \mathrm{C}$ for 45 seconds, annealing at $60^{\circ} \mathrm{C}$ for 1 minute and extension at $72^{\circ} \mathrm{C}$ for 1 minute. This was followed by a final extension at $72^{\circ} \mathrm{C}$ for 10 minutes. The PCR products were run on $1.5 \%$ agarose along with 100 bp DNA molecular weight marker (New England Biolabs, USA) at $5 \mathrm{~V} / \mathrm{cm}$ and visualized using gel documentation system (AlphaImager, Alpha Innotech, USA).

\section{Results}

\subsection{Prevalence of Microorganisms in the Mastitic Milk}

Mastitis is characterized by an increase in somatic cells, especially leukocytes, in the milk and by pathological changes in the mammary tissue [9]. The occurrence of mastitis is an outcome of interplay between the infectious agents and the management practices [10] and the overall loss caused by mastitis to the national economy has been estimated to be Rs 16,072 million [11]. Various microorganisms

Table 1. Primers used in PCR reaction for the detection of different organisms.

\begin{tabular}{|c|c|c|c|c|}
\hline S. No. & Organism & $\begin{array}{c}\text { Accession } \\
\text { No./Reference }\end{array}$ & $5^{\prime}$ to $3^{\prime}$ & $\begin{array}{l}\text { Amplicon Size } \\
\text { (bp) }\end{array}$ \\
\hline 1 & Escherichia coli & NC_002695.1 & $\begin{array}{l}\text { F: TGTTGGGTTAAGTCCCGCAA } \\
\text { R: CTCCAATCCGGACTACGACG }\end{array}$ & 230 \\
\hline 2 & Klebsiella pneumoniae & NC_06845.1 & $\begin{array}{l}\text { F: CTGCATTCGAAACTGGCAGG } \\
\text { R: GTTTACGGCGTGGACTACCA }\end{array}$ & 187 \\
\hline 3 & Staphylococcus aureus & СР000253.1 & $\begin{array}{l}\text { F: GAGCGGGACATGCCCTTTA } \\
\text { R: TGTCCGCCTTTTCTTCTTGC }\end{array}$ & 508 \\
\hline 4 & Streptococcus agalatiae & NC_004116.1 & $\begin{array}{l}\text { F: CTGTGAGATGGACCTGCGTT } \\
\text { R: ACGCCCAATAAATCCGGACA }\end{array}$ & 352 \\
\hline
\end{tabular}


implicated to cause mastitis includes Staphylococcus, Streptococcus and members of Enterobacteriaceae etc. In the present study, out of a total of sixty nine milk samples collected from mastitic animals (clinical and subclinical) positive using sodium lauryl sulphate (SLS) test fifty samples had bacterial growth and in rest of the nineteen samples there was absence of bacterial growth. Out of the fifty samples that showed bacterial colonies, only seven had single bacterial growth whereas rest of the 43 samples had mixed growth (Table 2).

Bacteriological culturing is considered most suitable, accurate and reliable method to confirm the presence of the causative organisms and many investigations have assured it as the gold standard for identifying intramammary infections and for developing a specific mastitis control program for a dairy herd. In the present study, out of a total of 69 samples collected from mastitic animals that were having either clinical/subclinical mastitis, 50 samples yielded bacterial growth. Similar findings have been reported by various workers [12] [13] where they observed no bacterial growth in 20 to $30 \%$ of milk samples taken from clinical mastitis cases even after 48 hours of conventional culture methods. Hussein [14] in a study reported that a positive bacterial isolation was obtained from 47 samples out of a total of 61 milk samples that showed positive results by the

Table 2. Organisms isolated from mastitic milk.

\begin{tabular}{|c|c|c|}
\hline & $\begin{array}{l}\text { (Total: } 50 \text { positive } \\
\text { samples) }\end{array}$ & Percent (\%) \\
\hline Single organism growth & Total: 7 & \\
\hline Streptococcus agalactiae & 3 & 42.86 \\
\hline Staphylococcus aureus & 4 & 57.14 \\
\hline Multiple organisms growth & Total: 43 & \\
\hline $\begin{array}{l}\text { Klebsiella pneumoniae + Streptococcus agalactiae } \\
+ \text { Staphylococcus aureus }\end{array}$ & 2 & 4.65 \\
\hline E. coli + Klebsiella pneumoniae & 3 & 6.97 \\
\hline $\begin{array}{l}\text { E. coli }+ \text { Staphylococcus aureus }+ \text { Streptococcus } \\
\text { agalactiae }\end{array}$ & 4 & 9.3 \\
\hline $\begin{array}{l}\text { E. coli }+ \text { Klebsiella pneumonia }+ \text { Staphylococcus } \\
\text { aureus }+ \text { Streptococcus agalactiae }\end{array}$ & 5 & 11.62 \\
\hline Staphylococcus aureus + Streptococcus agalactiae & 14 & 32.55 \\
\hline $\begin{array}{l}\text { E. coli }+ \text { Klebsiella pneumoniae }+ \text { Streptococcus } \\
\text { agalactiae }\end{array}$ & 15 & 34.88 \\
\hline Isolation of individual causative agent & Total: 124 & \\
\hline Streptococcus agalactiae & 43 & 34.67 \\
\hline Staphylococcus aureus & 29 & 23.38 \\
\hline E. coli & 27 & 21.77 \\
\hline Klebsiella pneumoniae & 25 & 20.16 \\
\hline
\end{tabular}


California mastitis test (CMT). Similarly Ergun [15] reported that upon comparing CMT and bacteriological results, microorganism's isolation rates were $57.3 \%$, $51.3 \%$ and $51.3 \%$ in CMT $+1,+2$, and +3 samples, respectively. Similarly Marogna [16] reported $30.6 \%$ of milk samples from goats with clinical signs of udder infection positive for bacterial isolation. Similar findings of less isolation rate in mastitic positive animals has been reported [17] who when compared cultural isolation with CMT and Whiteside Test (WST) revealed that isolation percentage was $67 \%$ and $40 \%$ respectively. In another study Kour [18] reported $49.1 \%$ positive isolation in SLS positive mastitic animals. Contrary to these findings a very high correlation between isolation rate and CMT positive too has been reported [19] [20]. Presence of less isolation in the mastitic animals is a common finding and has been attributed to many factors such as antimicrobial residues in cases of those animals which have been treated for mastitis [21]. The failure of some pathogens to grow in vitro in the study could also be due to the fact that certain microorganisms require specific and highly enriched growth medium [9] [18] which was not used in the present study.

\subsection{Isolation of the Causative Organisms}

Isolation of individual causative agent revealed that there were a total of 43 (34.67\%) Streptococcus agalactiae, 29 (23.38\%) Staphylococcus aureus, 27 (21.77\%) E. coli and 25 (20.16\%) Klebsiella pneumoniae isolated from all the samples on the basis of their cultural, morphological, biochemical characters and polymerase chain reaction. The presence of Staphylococcus and Streptococcus organisms in mastitic milk is a common finding which has been observed by various workers. Fujikura and Shibata [22] on bacteriological examination revealed that $72.4 \%$ of samples showed the presence of $S$. aureus, coagulase negative Staphylococcus (CoNS), S. agalactiae, S. dysgalactiae, S. uberis, Corynebacterium pyogenes, Pseudomonas aeruginosa, Bacillus cereus and members of Enterobacteriacae. Gonzalez [23] reported prevalence of $S$. aureus to be $43 \%$ from the mastitic animals. The data from various other studies indicated Staphylococcus to be the dominant organism among all the bacteria isolated from subclinical mastitic cases [24]-[29]. High rate of isolation of Staphylococcus spp. is mainly attributed due to the fact that the principal reservoirs of Staphylococcus spp. are the skin of the udder and milk of the infected gland. Additionally, Staphylococcus has the capacity to penetrate into the tissue, producing deep seated foci protected by a tissue barrier [9]. Also, the high frequency of staphylococcal mastitis is considered to be due to the existence of inadequate hygiene in the dairy industry, poor animal health services and lack of proper attention to the health of the mammary gland in general.

A combination of all or two or more than two organisms was found in 43/50 (86\%) samples indicating that more than one organism was causing mastitis. The above finding is similar to the findings of many workers in which they reported the presence of mixed infection [18] [20] [30]. 


\subsection{Antibiotic Sensitivity Testing}

Antimicrobial Sensitivity test helps to understand the resistance and susceptibility of bacteria towards a particular drug and thus helping in the choice of drug to be used for treatment. Antibiogram study of the individual organisms isolated viz., Streptococcus agalactiae, Staphylococcus aureus, E. coli and Klebsiella pneumonia from the mastitic milk was done (Table 3) and E. coli revealed highest sensitivity to azithromycin, chloramphenicol (100\%) each, followed by erythromycin, cefalexin (92.5\%) each, ciprofloxacin $(70.37 \%)$ and sparfloxacin (66.66\%) where as highest resistance was observed against amoxicillin (100\%), followed by teicoplanin (66\%), vancomycin (66\%), ofloxacin (63\%) and tetracycline $(37.03 \%)$. The results of the study were similar to the earlier findings [18] [31] [32].

In case of Klebsiella pneumoniae, highest sensitivity was observed to azithromycin, gentamicin (100\%) each, followed by cephalexin (96\%), ciprofloxacin (76\%), clotrimazole (72\%) doxycycline and vancomycin (64\%) each whereas highest resistance to amoxicillin and teicoplanin (100\%) each, followed by erythromycin (76\%), sparfloxacin (60\%), gatifloxacin (56\%) and ofloxacin (40\%). In an earlier study it was observed that Klebsiella pneumoniae was susceptible to ofloxacin, gentamicin, amikacin, pefloxacin and ciprofloxacin whereas resistance to carbenicillin, piperacillin, ampicillin, co-trimoxazole, cefotaxime, chloramphenicol and tetracycline similar to the findings of our study [33].

Table 3. Antibiotic Sensitive (S), Intermediate (I) and Resistant (R) per cent of Escherichia coli, Klebsiella pneumoniae, Staphylococcus aureus and Streptococcus agalactiae.

\begin{tabular}{|c|c|c|c|c|c|c|c|c|c|c|c|c|c|}
\hline \multirow[t]{2}{*}{$\begin{array}{l}\text { Sr. } \\
\text { No. }\end{array}$} & \multirow[t]{2}{*}{ Antibiotic } & \multicolumn{3}{|c|}{ E. coli } & \multicolumn{3}{|c|}{$\begin{array}{c}\text { Klebsiella } \\
\text { pneumoniae }\end{array}$} & \multicolumn{3}{|c|}{$\begin{array}{c}\text { Staphylococcus } \\
\text { aureus }\end{array}$} & \multicolumn{3}{|c|}{$\begin{array}{c}\text { Streptococcus } \\
\text { agalactiae }\end{array}$} \\
\hline & & S (\%) & I (\%) & $\mathrm{R}(\%)$ & S (\%) & I (\%) & $\mathrm{R}(\%)$ & $\mathrm{S}(\%)$ & I (\%) & $\mathrm{R}(\%)$ & $S(\%)$ & $\mathrm{I}(\%)$ & R (\%) \\
\hline 1 & Chloramphenicol(C) (30 mcg) & 100 & 0 & 0 & 100 & 0 & 0 & 72.41 & 0 & 31.03 & 72 & 0 & 28 \\
\hline 2 & Erythromycin (E) (15 mcg) & 92.50 & 0 & 7.5 & 24 & 0 & 76 & 34.48 & 27.58 & 31.03 & 58.13 & 0 & 41.86 \\
\hline 3 & Tetracycline (TE) (30 mcg) & 44.44 & 19 & 37.03 & 56 & 8 & 36 & 65.51 & 0 & 34.48 & 23.25 & 9.3 & 67.44 \\
\hline 4 & Amoxicillin (AMX) (10 mcg) & 0 & 0 & 100 & 0 & 0 & 100 & 6.89 & 0 & 93.10 & 6.97 & 0 & 93.03 \\
\hline 5 & Co-trimoxazole (COT) $(25 \mathrm{mcg})$ & 25.90 & 14.10 & 60 & 72 & 0 & 28 & 58.62 & 27.39 & 13.79 & 76.74 & 9.3 & 13.9 \\
\hline 6 & Ciprofloxacin (CIP) (5 mcg) & 70.37 & 0 & 29.62 & 76 & 0 & 24 & 100 & 0 & 0 & 95.34 & 0 & 4.6 \\
\hline 7 & Gentamicin (GEN) (10 mcg) & 100 & 0 & 0 & 100 & 0 & 0 & 58.62 & 0 & 41.37 & 95.34 & 0 & 4.6 \\
\hline 8 & Cephalexin $(\mathrm{CN})(30 \mathrm{mcg})$ & 92.5 & 0 & 7.5 & 96 & 0 & 4 & 79.31 & 0 & 20.68 & 76.74 & 0 & 23.25 \\
\hline 9 & Ofloxacin (OF) (5 mcg) & 37 & 0 & 63 & 36 & 36 & 40 & 68.96 & 31.03 & 0 & 100 & 0 & 0 \\
\hline 10 & Sparfloxacin (SPX) (5 mcg) & 66.66 & 0 & 33.33 & 40 & 0 & 60 & 100 & 0 & 0 & 81.39 & 9.3 & 9.3 \\
\hline 11 & Gatifloxacin (GAT) (5 mcg) & 59.25 & 11.11 & 29.62 & 28 & 16 & 56 & 48.27 & 20.68 & 31.03 & 76.74 & 2.32 & 20.93 \\
\hline 12 & Teicoplanin (TEI) (30 mcg) & 44 & 0 & 66 & 0 & 0 & 100 & 72.41 & 27.58 & 0 & 70 & 0 & 30 \\
\hline 13 & Azithromycin (AZM) (15 mcg) & 100 & 0 & 0 & 100 & 0 & 0 & 100 & 0 & 0 & 90.69 & 9.3 & 0 \\
\hline 14 & Vancomycin (VA) (30 mcg) & 44 & 0 & 66 & 64 & 0 & 36 & 68.96 & 0 & 31.03 & 46.51 & 18.6 & 34.88 \\
\hline 15 & Doxycycline (DO) & 37 & 37 & 26 & 64 & 0 & 36 & 100 & 0 & 0 & 0 & 9.3 & 90.69 \\
\hline
\end{tabular}


Antibiotic sensitivity of Staphylococcus aureus revealed highest sensitivity to ciprofloxacin, doxycycline, azithromycin, sparfloxacin (100\%) each followed by cefalexin (79.31\%), teicoplanin, chloramphenicol (72.41\%) each, vancomycin and ofloxacin (68.96\%) each and highest resistance to amoxicillin (93.1\%) followed by gentamicin $(41.37 \%)$, tetracycline (34.48\%) erythromycin, vancomycin and gatifloxacin (31.03\%) each. Mir [31] observed sensitivity to gentamicin in Staphylococcus which is in contrast to the findings of our study however other workers have reported susceptibility of Staphylococcus to ceftriaxone, ciprofloxacin, erythromycin and gentamicin similar to the findings of our study [34] [35] [36].

Antibiotic sensitivity of Streptococcus agalactiae revealed highest sensitivity to ofloxacin (100\%), followed by ciprofloxacin and gentamicin (95.34\%) each, azithromycin (90.69\%) and sparfloxacin (81.39\%), co-trimoxazole, cefalexin (76.74\%) each and highest resistance to amoxicillin (93.03\%) followed by doxycycline (90.69\%), tetracycline (67.33\%), erythromycin (41.86\%) and vancomycin (34.88\%) which is almost similar to the findings of similar earlier studies [37] [38].

Thus, from the present study it could be concluded that most frequently isolated organisms form mastitic milk were Streptococcus agalactiae, Staphylococcus aureus, E. coli and Klebsiella pneumoniae and there was a higher percentage of mixed infection in comparison to the single infection. Further, antibiotic sensitivity test on the isolated bacteria revealed azithromycin, ciprofloxacin, sparfloxacin and ofloxacin to be the most sensitive whereas amoxicillin, erythromycin, tetracycline and vancomycin to be the most resistant drugs.

\section{Acknowledgements}

The authors are grateful to the University Grant Commission (UGC), India for the financial support MRP-MAJOR-VETE-2013-31898 (General). The authors are also thankful to the Director Research, GADVASU for providing the necessary laboratory facilities.

\section{References}

[1] NDDB 2015-16. http://www.nddb.org/information/stats/milkprodindia

[2] Miller, R.H., Paape, M.J., Fulton, L.A. and Schutz, M.M. (1993) The Relationship of Milk Somatic Cell Count to Milk Yields for Holstein Heifers after First Calving. Journal of Dairy Science, 76, 728-733. https://doi.org/10.3168/jds.S0022-0302(93)77396-8

[3] Radostitis, O., Gay, C., Hinchcliff, K. and Constable, P. (2006) Veterinary Medicine A Textbook of the Diseases of Cattle, Sheep, Pigs, Goats and Horses. 10th Edition, WB Saunders, Philadelphia.

[4] Hogveen, H., Pyorala, S., Waller, K.P., Hogan, J.S., Lam, T.J.G.M., Oliver, S.P., Schukken, Y.H., Barkema, H.W. and Hillerton, J.E. (2011) Current Status and Future Challenges in Mastitis Research. NMC Annual Meeting Proceedings, Arlington, 23-26 January 2011, 36-48.

[5] Kuang, Y., Tani, K., Synnott, A.J., Ohshima, K., Higuchi, H., Nagahata, H. and Tan- 
ji, Y. (2009) Characterization of Bacterial Population of Raw Milk from Bovine Mastitis by Culture-Independent PCR-DGGE Method. Biochemical Engineering Journal, 45, 76-81. https://doi.org/10.1016/j.bej.2009.02.010

[6] CLSI (2015) Performance Standards for Antimicrobial Disc Susceptibility Tests. Approved Standards 12 Edition, CLSI.

[7] Sambrook, J. and Russell, D.W. (2001) Molecular Cloning: A Laboratory Manual. Cold Spring Harbour, Cold Spring Laboratory Press, New York.

[8] Untergasser, A., Cutcutache, I., Koressaar, T., Ye, J., Faircloth, B.C., Remm, M. and Rozen, S.G. (2012) Primer 3 New Capabilities and Interfaces. Nucleic Acids Research, 40, e115. https://doi.org/10.1093/nar/gks596

[9] Ranjan, R., Gupta, M.K., Singh, S. and Kumar, S. (2010) Current Trend of Drug Sensitivity in Bovine Mastitis. Veterinary World, 3, 17-20.

[10] Sudhan, N.A. and Sharma, N. (2010) Mastitis: An Important Production Disease of Dairy Animals. Sarva Manav Vikash Samiti, Gurgaon, India, 72-88.

[11] Singh, P.J. and Singh, P.B. (1994) A Study of Economic Losses Due to Mastitis in India. Indian Journal of Dairy Science, 47, 265-272.

[12] Taponen, S., Salmikivi, L., Simojoki, H., Koskinen, M.T. and Pyorala, S. (2009) Real-Time Polymerase Chain Reaction-Based Identification of Bacteria in Milk Samples from Bovine Clinical Mastitis with No Growth in Conventional Culturing. Journal of Dairy Science, 92, 2610-2617. https://doi.org/10.3168/jds.2008-1729

[13] Bradley, A. (2002) Bovine Mastitis: An Evolving Disease. The Veterinary Journal, 2, 116-128. https://doi.org/10.1053/tvjl.2002.0724

[14] Hussein, S.A. (2012) Prevalence and Bacterial Etiology of Subclinical Mastitis in Dairy Cows in Al Sulaimaniyah District. Kufa Journal for Veterinary Medical Sciences, 3, 190-203.

[15] Ergun, Y., Aslantas, O., Dogruer, G., Kireçci, E., Saribay, M.K., Ates, C.T., Ulku, A. and Demir, C. (2009) Prevalence and Etiology of Subclinical Mastitis in Awassi Dairy Ewes in Southern Turkey. Turkish Journal of Veterinary and Animal Sciences, 33, 477-483.

[16] Marogna, G., Pilo, C., Vidili, A., Tola, S., Schianchi, G. and Leori, S.G. (2012) Comparison of Clinical Findings, Microbiological Results, and Farming Parameters in Goat Herds Affected by Recurrent Infectious Mastitis. Small Ruminant Research, 102, 74-83. https://doi.org/10.1016/j.smallrumres.2011.08.013

[17] Lazzari, K., Kuusela, P. and Korhonen, T.K. (2002) Bacterial Plasminogen Activators and Receptors. FEMS Microbiology Reviews, 25, 531-552.

[18] Kour, G., Chandra, M., Kaur, G., Narang, D., Gupta, D.K., Arora, A.K. and Sharma, N.S. (2017) Prevalence of Mastitis Causing Organism and Their Antibiotic Resistance Pattern in Dairy Farms. Indian Journal of Dairy Science, 70, 587-592.

[19] Heleili, N., Ayachi, A., Melizi, M., Kassah, A.L. and Mamache, B. (2012) Prevalence of Subclinical Bovine Mastitis and the in Vitro Sensitivity of Bacterial Isolates in Batna Governorate, East of Algeria. Journal of Animal Science Advances, 2, 576-582.

[20] Saidi, R., Khelef, D. and Kaidi, R. (2013) Bovine Mastitis: Prevalence of Bacterial Pathogens and Evaluation of Early Screening Test. African Journal of Microbiology Research, 7, 777-782.

[21] Azmi, D., Al-Dabbas, H. and Al-Dabbas, F. (2008) Prevalence and Distribution of Mastitis Pathogens and Their Resistance against Antimicrobial Agents in Dairy Cows in Jordan. American Journal of Animal and Veterinary Sciences, 3, 36-39. 
https://doi.org/10.3844/ajavsp.2008.36.39

[22] Fujikura, P. and Shibata, S. (1965) Bovine Mastitis Incidences in Rural Areas of Japan. Journal of Dairy Science, 5, 65-72.

[23] Gonzalez, R.N., Girado, J.A. and Busso, J.J. (1980) Investigation of Subclinical Mastitis (in Argentina) II. Bacterial Agents. Journal of Veterinary Medicine, 61, 225-234.

[24] Swartz, R., Jooste, P.J. and Novello, J.C. (1984) Prevalence and Types of Bacteria Associated with Subclinical Mastitis in Bloemfontein Dairy Herds. Journal of the South African Veterinary Association, 55, 61-64.

[25] Schukken, Y.H., Grommers, F.J., Geer, D., Brand, A. and Vandegeer, D. (1989) Incidence of Clinical Mastitis on Farms with Low Somatic Cell Counts in Bulk Milk. Veterinary Record, 125, 60-63. https://doi.org/10.1136/vr.125.3.60

[26] Kerrodego, O. and Tareke, F. (2003) Bovine Mastitis in Selected Areas of Southern Ethiopia. Tropical Animal and Health Production, 35, 197-205. https://doi.org/10.1023/A:1023352811751

[27] Verma, T.N., Mandal, L.N. and Sinha, B.K. (1978) Studies on Subclinical Mastitis with Special Refrence to Bacterial Isolation and Its Public Health Importance. Indian Journal of Public Health, 22, 249-253.

[28] Singh, K.B., Randhawa, S.S. and Nauriyal, D.C. (1988) Studies on the Cultural Pattern and Antibiogram of Isolates from Clinical Mastitis. Indian Journal of Animal Health, 27, 17-19.

[29] Wadhwa, D.R., Rao, V.N., Prasad, B., Mandeep, S. and Sharma, M. (1996) Clinical Mastitis in Cows in Palam Valley of Himachal Pradesh: Etiology and Antibiogram of Bacterial Isolates. Indian Veterinary Journal, 73, 1271-1273.

[30] Hawari, A.D. and Al-Dabbas, F. (2008) Prevalence and Distribution of Mastitis Pathogens and Their Resistance against Antimicrobial Agents in Dairy Cows in Jordan. American Journal of Animal and Veterinary Sciences, 3, 36-39. https://doi.org/10.3844/ajavsp.2008.36.39

[31] Mir, A.Q., Bansal, B.K. and Gupta, D.K. (2014) Subclinical Mastitis in Machine Milked Dairy Farms in Punjab: Prevalence, Distribution of Bacteria and Current Antibiogram. Veterinary World, 7, 291-294. https://doi.org/10.14202/vetworld.2014.291-294

[32] Moges, N., Asfaw, Y., Belihu, K. and Tadesse, A. (2011) Antimicrobial Susceptibility of Mastitis Pathogen from Smallholder Dairy Herds in and around Gondar. Ethiopian Journal of Animal and Veterinary Advances, 10, 1616-1622. https://doi.org/10.3923/javaa.2011.1616.1622

[33] Sikarwar, A.S. and Batra, H.V. (2011) Prevalence of Antimicrobial Drug Resistance of Klebsiella pneumoniae in India. International Journal of Bioscience, Biochemistry and Bioinformatics, 1, 211-215. https://doi.org/10.7763/IJBBB.2011.V1.38

[34] Unakal, C.G. and Kaliwal, B.B. (2010) Prevalence and Antibiotic Susceptibility of Staphylococcus aureus from Bovine Mastitis. Veterinary World, 3, 65-67.

[35] Uddin, M.A., Mottazim-ul-Haque, H.M. and Noor, R. (2010) Isolation and Identification of Pathogenic Escheichia coli, Klebsiella spp. and Staphylococcus spp. in Raw Milk Samples Collected from Different Areas of Dhaka City, Bangladesh. Stanford Journal of Microbiology, 1, 19-23.

[36] Prabhu, K.N., Isloor, S., Hegde, R., Rathnamma, D. and Veeregowda, B.M. (2013) Development of Polymerase Chain Reaction for Detection of Predominant Streptococcal Isolates Causing Subclinical Bovine Mastitis. Indian Journal of Biotechnology, 12, 208-212. 
[37] Krishnaveni, N., Isloor, S.K., Suryanarayana, V.V.S., Rathnamma, D., Veeregowda, B.M., Nagaraja, C.S. and Sundareshan, S. (2014) Antibiogram Profile of Group B Streptococci Isolated from Bovine Mastitis Cases. Veterinary Clinical Science, 2, $10-15$.

[38] Jain, B., Tewari, A., Bhandari, B.B. and Jhala, M.K. (2012) Antibiotic Resistance and Virulence Genes in Streptococcus agalactiae Isolated from Cases of Bovine Subclinical Mastitis. Veterinary Archievs, 82, 423-432. 